\title{
KECAKAPAN HUKUM DAN LEGALITAS TANDA TANGAN SEORANG TERPIDANA DALAM MENANDATANGANI AKTA OTENTIK
}

\author{
Danang Wirahutama, * Widodo Tresno Novianto, Noor Saptanti \\ Program Magister Kenotariatan Fakultas Hukum Universitas Sebelas Maret \\ Jalan Ir. Sutami No.36A, Jebres, Kota Surakarta, Jawa Tengah \\ 57126danangwirahutama@ymail.com; novianto@,consultant.com; saptanti@yahoo.co.id
}

\begin{abstract}
The existence of a notary as a general official is to accommodate all matters relating to civil law, especially the needs of the community will be proof by making authentic deed. Legal skills and legality of signature tapers are very important because they can result in the authentic deed becoming a deed under hand. The research method used is normative juridical. The results of this study that convicts in prisons are capable of acting in law by signing or becoming a deed before a notary. The ability to act within the law as provided in article 1330 of the Civil Code does not mention that persons who are in prisons are subject to criminal sanctions are declared incapable of acting in law, as provided for in article 1 paragraph (3) of the Civil Code, there is no punishment which results in civil death, or the loss of any citizenship rights.
\end{abstract}

Keywords: Authentic deed; lawful; signature.

\begin{abstract}
Abstrak
Eksistensi notaris sebagai pejabat umum adalah mengakomodir segala hal yang berkaitan dengan hukum keperdataan, khususnya kebutuhan masyarakat akan pembuktian dengan pembuatan akta otentik. Kecakapan hukum dan legalitas tanda tangan penghadap sangat penting diperhatikan karena dapat mengakibatkan akta otentik tersebut menjadi akta dibawah tangan. Metode penelitian yang digunakan adalah yuridis normatif. Hasil penelitian ini bahwa terpidana di lembaga pemasyarakatan cakap bertindak dalam hukum dengan menandatangani atau menjadi akta di hadapan notaris. Kecakapan bertindak dalam hukum sebagaimana pasal 1330 Kitab Undang-Undang Hukum Perdata tidak ada menyebut bahwa orang yang ada dalam lembaga pemasyarakatan menjalani sanksi pidana dinyatakan tidak cakap bertindak dalam hukum, sebagaimana ditentukan dalam pasal 1 ayat (3) Kitab Undang-Undang Hukum Perdata, bahwa tiada suatu hukuman pun yang mengakibatkan kematian perdata, atau hilangnya segala hak kewargaan.
\end{abstract}

Kata Kunci: Akta otentik; cakap hukum; tanda tangan.

\section{A. Pendahuluan}

Perkembangan kehidupan bermasyarakat telah meningkatkan intensitas dan kompleksitas hubungan hukum dari subjek hukum yang harus mendapatkan perlindungan dan kepastian berdasarkan alat bukti yang menentukan dengan jelas hak dan kewajibannya (Kambey, 2013). Oleh karena itu, agar terdapat perlindungan, kepastian, dan ketertiban hukum, maka setiap perbuatan h u k u m h r s a d k g i a t a n pengadministrasian hukum (law administrating) yang tepat dan tertib (Closen, Ahlers, Jarvis, Morris, \& Spyke, 1997).
Pengadministrasian hukum diperlukan untuk menghindari terjadinya hubungan hukum yang cacat dan dapat merugikan subyek hukum maupun masyarakat (Closen et al., 1997).

Hak asasi melekat pada diri manusia sejak lahir. Menurut hukum, manusia termasuk subjek hukum yang merupakan pendukung hak dan kewajiban. Hak adalah wewenang yang di berikan hukum kepada subjek hukum, sedangkan kewajiban adalah beban yang diberikan oleh hukum kepada subjek hukum (Ismamuddin, 2010). Sementara itu, kemampuan subjek hukum 
untuk melakukan perbuatan hukum yang dipandang sah oleh hukum disebut kecakapan hokum (Lestari, 2008). Kecakapan hukum sangat erat kaitannya dengan perbuatan seseorang yang akan melakukan tindakan hukum, misalnya membuat perikatan ataupun perjanjian. Kecakapan hukum menjadi salah satu syarat sahnya suatu perjanjian dibuat. Hal ini secara jelas diatur di dalam Pasal 1320 Kitab Undang-Undang Hukum Perdata (selanjutnya disebut KUHPerdata).

Setiap orang dianggap cakap melakukan tindakan hukum kecuali jika yang bersangkutan oleh Undang-Undang dinyatakan tidak cakap melakukan perbuatan hukum. Pasal 330, 433, dan Pasal 1330 KUHPerdata tidak menyebutkan tentang seseorang yang dinyatakan cakap dalam melakukan perbuatan hukum. Pasal 1330 KUHPerdata mengatur mengenai subjek hukum yang tidak cakap untuk membuat suatu perjanjian, yaitu:

1. Orang-orang yang belum dewasa;

2. Mereka yang ditaruh di bawah pengampuan; dan

3. Orang-orang perempuan, dalam hal-hal yang ditetapkan oleh undang-undang dan pada umumnya semua orang kepada siapa undang-undang telah melarang membuat perjanjian-perjanjian tertentu.

Ketentuan Nomor 3 ini menjadi hapus dengan berlakunya Undang-Undang Nomor 1 Tahun 1974 tentang Perkawinan. Dilihat dari isi Pasal 1330 KUHPerdata ini dapat ditafsirkan bahwa subjek hukum yang cakap melakukan perbuatan hukum ataupun membuat perjanjian adalah orang-orang yang sudah dewasa dan orang yang tidak ditaruh di bawah pengampuan(Hikmah, 2015).

Terkait dengan kecakapan hukum, notaris memiliki peran dalam mengidentifikasi apakah penghadap, dalam hal ini adalah subjek hukum yang akan melakukan perbuatan hukum, sudah memenuhi unsur cakap atau belum (Stia, 2008). Lebih jauh, peran notaris sangat penting dan dibutuhkan dalam kegiatan bermasyarakat (Ramelan, 1986). Notaris dalam melaksanakan tugas jabatannya semata-mata hanya untuk kepentingan umum, bukan untuk kepentingan diri pribadi notaris itu sendiri(Subekti, 2006). Oleh sebab itu, notaris sebagai pejabat umum memiliki peran yang penting dalam menegakkan hukum di Indonesia. Secara sosiologis, ekonomis, politis serta psikologis, profesi notaris dianggap memiliki kedudukan yang tinggi dalam struktur masyarakat pada umumnya (Gnoffo, 1997). Eksistensi notaris di kalangan pejabat umum (openbaar ambtenaar) adalah untuk mengakomodir segala hal yang berkaitan dengan hukum keperdataan, khususnya kebutuhan masyarakat akan pembuktian dengan dilandasi Undang-Undang Nomor 2 Tahun 2014 tentang Perubahan Atas UndangUndang Nomor 30 Tahun 2004 tentang Jabatan Notaris (selanjutnya disebut UUJNP) sebagaimana tertuang dalam Pasal 1 ayat (1) UUJN-P bahwa notaris adalah pejabat umum yang berwenang untuk membuat akta autentik dan memiliki kewenangan lainnya sebagaimana dimaksud dalam UndangUndang ini atau berdasarkan UndangUndang lainnya.

Kewenangan notaris sebagaimana dimaksud Pasal 15 UUJN-P dengan profesinya sebagai pembuat akta otentik disertai dengan perkembangan kebutuhan masyarakat yang begitu pesat dan dinamis telah meningkatkan intensitas dan kompleksitas hubungan hukum yang tentunya memerlukan kepastian, ketertiban, dan perlindungan hukum yang berintikan kebenaran dan keadilan. Hal ini yang menjadi landasan filosofis dari terbentuknya UndangUndang Jabatan Notaris melalui produk yang dikeluarkan oleh notaris yaitu akta otentik guna menjamin kepastian hukum dan perlindungan hukum setiap pengguna jasa notaris(Rahman, 2014).

Berkaitan dengan perbuatan hukum yang dilakukan di hadapan notaris, salah satunya adalah pembuatan akta. Dalam pembuatan akta, tanda tangan merupakan salah satu unsur yang penting yang harus diperhatikan oleh notaris. Tanda tangan merupakan suatu pernyataan kemauan pembuat tanda tangan (penandatanganan) bahwa dengan membubuhkan tanda tangan di bawah tulisan yang ia tulis, maka ia menghendaki tulisan itu dianggap benar oleh hukum. Pengertian tanda tangan dalam arti umum dapat didefinisikan sebagai suatu susunan huruf atau tanda berupa tulisan dari yang menandatangani, dengan mana orang 
yang membuat pernyataan atau keterangan tersebut dapat di individualisasikan. Suatu pernyataan yang dibuat secara tertulis termasuk juga akta harus dibubuhi tanda tangan dari yang bersangkutan (Handayani, 2009).

Tanda tangan merupakan keharusan dalam suatu akta yang bertujuan untuk membedakan akta yang satu dengan akta yang lain atau dari akta yang dibuat orang lain agar terpenuhinya kepastian hukum (Closen, 1999). Fungsi tanda tangan adalah untuk memberi ciri seseorang yang menandatangani atau untuk mengindividualisir sebuah akta yang ditandatanganinya (Rains \& Young, 2006). Akta yang dibuat oleh seseorang dengan orang lain dapat diidentifikasi dari tanda tangan yang dibubuhkan pada akta-akta tersebut, di mana pencantuman nama atau tanda tangan yang ditulis dengan huruf balok tidaklah cukup karena dari tulisan huruf balok itu tidak tampak ciri-ciri atau sifat-sifat pembuat (Sherblom, 1988). Mekanisme penandatanganan akta otentik tidak hanya terbatas pada persoalan bahwa akta tersebut harus ditandatangani namun penandatangan akta tersebut juga harus di hadapan notaris sebagaimana telah diatur dalam Pasal 16 ayat (1) huruf m UUJN-P bahwa "membacakan akta di hadapan penghadap dengan dihadiri oleh paling sedikit 2 (dua) orang saksi, atau 4 (empat) orang saksi khusus untuk pembuatan Akta wasiat di bawah tangan, dan ditandatangani pada saat itu juga oleh penghadap, saksi, dan Notaris".

Membacakan akta sampai pada penandatanganan adalah satu kesatuan dari peresmian akta di mana sebelum akta tersebut di tandatangani terlebih dahulu akta tersebut dibacakan di depan para pihak yang bersangkutan guna menyampaikan kebenaran isi akta dengan keinginan para pihak kemudian akta tersebut ditandatangani tentunya di hadapan para pihak dan dua orang saksi. Ketika menjalankan profesinya tersebut, tidak jarang notaris dihadapkan pada perbuatan-perbuatan yang menyimpang dari ketentuan yang berlaku atau melakukan perbuatan melawan hukum. Kecakapan hukum dan legalitas tanda tangan penghadap sangat penting diperhatikan karena dapat mengakibatkan kekuatan pembuktian akta otentik tersebut menjadi akta di bawah tangan. Perbuatan melawan hukum diartikan sebagai kesalahan perdata yang dilakukan oleh seseorang yang mengakibatkan kerugian pada orang lain dengan melanggar hak dan kewajiban yang ditentukan oleh hukum yang dapat dimintakan ganti rugi terhadap kerugian yang diakibatkannya (Fuady, 2010). Artikel ini bertujuan untuk membahas mengenai kecakapan hukum dan legalitas tandatangan seorang terpidana dalam membuat akta otentik.

\section{B. Metode Penelitian}

Penelitian yang digunakan adalah penelitian hukum normatif. Jenis data yang digunakan dalam penelitian ini adalah data sekunder, yaitu bahan hukum primer, sekunder, dan tersier. Bahan hukum primer meliputi Undang-Undang Nomor 2 Tahun 2014 tentang Perubahan Undang-Undang Nomor 30 Tahun 2004 tentang Jabatan Notaris dan KUHPerdata. Bahan hukum sekunder meliputi bahan-bahan kepustakaan yang didapat dari literatur, jurnal, dokumendokumen, laporan, desertasi, tesis, dan lain sebagainya. Sementara, bahan hukum tersier adalah kamus.

Teknik pengumpulan data yang digunakan dalam penelitian ini adalah studi kepustakaan, yaitu menghimpun dan menelaah informasi yang relevan dengan masalah atau topik yang akan diteliti. Informasi tersebut dapat diperoleh dari literatur, jurnal ilmiah, tesis, disertasi, peraturan-peraturan dan sumber lainnya. Teknik analisis data dalam penelitian ini menggunakan teknik penafsiran hukum, yaitu menerangkan, menjelaskan, menegaskan baik dalam arti memperluas, membatasi ataupun mempersempit sumber-sumber hukum yang ada dalam rangka penggunaannya untuk memecahkan masalah atau persoalan yang sedang dihadapi.

\section{Hasil dan Pembahasan \\ 1. Konsep Cakap Hukum}

Kecakapan berasal dari kata dasar cakap, yang berarti sanggup melakukan sesuatu; mampu; dapat; mempunyai kemampuan dan kepandaian untuk mengerjakan sesuatu. Kecakapan (handelings bekwaamheid) memiliki makna yang erat kaitannya dengan kemampuan 
seseorang untuk memperhitungkan konsekuensi atau akibat hukum dari perbuatan yang dilakukannya. Kecakapan merupakan unsur melakukan suatu perbuatan hukum. Berbagai macam hukum dan perundang-undangan yang mengatur tentang hal kecakapan hukum melakukan perbuatan hukum baik tertulis maupun tidak tertulis. Kecakapan menurut KUHPerdata sering dikaitkan langsung dengan batas usia seseorang, sedangkan dalam Hukum adat dianggap telah cakap apabila telah menikah. Kecakapan sering kali disebut sebagai faktor utama ketika ingin melakukan suatu perbuatan di masyarakat pada umumnya (Arifianto, Rato, \& Sriono, 2014).

Kecakapan hukum adalah kemampuan seseorang terkait hak dan kewajiban untuk melakukan suatu tindakan hukum dengan adanya akibat hukum yang telah ditentukan dalam peraturan perundang-undangan. Kecakapan untuk melakukan perbuatan hukum diartikan sebagai kemungkinan untuk melakukan perbuatan hukum secara mandiri yang mengikat diri sendiri tanpa dapat diganggu gugat (Dewi, 2008). Kecakapan untuk melakukan perbuatan hukum pada umumnya diukur dari person (pribadi), yaitu diukur dari standar usia kedewasaan (meerderjarig); dan Rechtspersoon (badan hukum), yang diukur dari aspek kewenangan (Hernoko, 2010).

Kecakapan pihak-pihak yang membuat perjanjian menurut Pasal 1329 KUHPerdata adalah cakap untuk membuat suatu perikatanperikatan, jika ia oleh undang-undang tidak dinyatakan tak cakap. Dikatakan tidak cakap bertindak menurut hukum menurut Pasal 1330 angka 1 dan 2 KUHPerdata yaitu orangorang yang belum dewasa dan mereka yang ditaruh di bawah pengampuan. Dikatakan belum dewasa menurut Pasal 330 KUHPerdata adalah mereka yang belum mencapai umur genap dua puluh satu tahun, dan tidak lebih dahulu telah kawin. Menurut Pasal 47 Undang-undang Nomor 1 Tahun 1974 tentang Perkawinan, adalah anak yang telah mencapai umur 18 (delapan belas) tahun atau sudah pernah melangsungkan perkawinan, dapat melakukan perbuatan hukum baik di dalam dan di luar pengadilan. Dianggap tidak cakap adalah apabila seseorang berdasarkan ketentuan peraturan perundang-undangan tidak mampu membuat sendiri perjanjian-perjanjian dengan akibat hukum yang sempurna. Pasal 1330 KUHPerdata menyebutkan tentang orang yang tidak cakap untuk membuat perjanjian, yaitu:

1. Orang-orang yang belum dewasa (belum mencapai usia 21 tahun);

2. Orang yang berada dibawah pengampuan(curatele);

3. Orang-orang perempuan yang telah kawin. Ketentuan ini menjadi hapus dengan berlakunya Undang-Undang Nomor 1 Tahun 1974 tentang Perkawinan. Karena Pasal 31 UndangUndang ini menentukan bahwa hak dan kedudukan suami istri adalah seimbang dan masing-masing berhak untuk melakukan perbuatan hukum.

Akibat hukum apabila suatu perbuatan hukum dilakukan oleh orang yang tidak cakap adalah dapat dibatalkannya perbuatan hukum tersebut pihak tidak cakap tersebut, baik melalui wakilnya atau dirinya sendiri sesudah dewasa.

\section{Konsep Tanda Tangan dalam Hukum}

Tanda tangan merupakan suatu pernyataan kemauan pembuat tanda tangan (penandatanganan) bahwa dengan membubuhkan tanda tangan di bawah tulisan yang ia tulis, maka ia menghendaki tulisan itu dianggap benar oleh hukum. Pengertian tanda tangan dalam arti umum dapat didefinisikan sebagai suatu susunan huruf atau tanda berupa tulisan dari yang menandatangani, dengan mana orang yang membuat pernyataan atau keterangan tersebut dapat di individualisasikan. Suatu pernyataan yang dibuat secara tertulis termasuk juga akta harus dibubuhi tanda tangan dari yang bersangkutan(Handayani, 2009).

Tanda tangan merupakan keharusan dalam suatu akta yang bertujuan untuk membedakan akta yang satu dengan akta yang lain atau dari akta yang dibuat orang lain agar terpenuhinya kepastian hukum (Closen, 1999). Fungsi tanda tangan adalah untuk memberi ciri seseorang yang menandatangani atau untuk mengindividualisir sebuah akta yang ditandatanganinya (Rains \& Young, 2006). Akta yang dibuat oleh A dan B dapat diidentifikasi dari tanda tangan yang 
dibubuhkan pada akta-akta tersebut, di mana pencantuman nama atau tanda tangan yang ditulis dengan huruf balok tidaklah cukup karena dari tulisan huruf balok itu tidak tampak ciri-ciri atau sifat-sifat pembuat (Sherblom, 1988).

Mekanisme penandatanganan akta otentik tidak hanya terbatas pada persoalan bahwa akta tersebut harus ditandatangani namun penandatangan akta tersebut juga harus di hadapan notaris sebagaimana telah diatur dalam Pasal 16 ayat (1) huruf m UUJNP bahwa "membacakan akta di hadapan penghadap dengan dihadiri oleh paling sedikit 2 orang saksi, atau empat orang saksi khusus untuk pembuatan akta wasiat di bawah tangan dan ditandatangani pada saat itu juga oleh penghadap, saksi, dan notaris".

Membacakan akta sampai pada penandatanganan adalah satu kesatuan dari peresmian akta di mana sebelum akta tersebut di tandatangani terlebih dahulu akta tersebut dibacakan di depan para pihak yang bersangkutan guna menyampaikan kebenaran isi akta dengan keinginan para pihak kemudian akta tersebut ditandatangani tentunya di hadapan para pihak dan dua orang saksi. Penandatanganan suatu dokumen secara umum mempunyai tujuan sebagai berikut.

1. Bukti (evidence): suatu tanda tangan mengidentifikasikan penandatangan d e $\mathrm{n} \mathrm{g}$ a $\mathrm{n}$ d o k u e $\mathrm{n}$ y a $\mathrm{ng}$ ditandatanganinya. Pada saat penandatangan membubuhkan tanda tangan dalam bentuk yang khusus, tulisan tersebut akan mempunyai hubungan (attribute) dengan penandatangan;

2. Ceremony: penandatanganan suatu dokumen akan berakibat si penandatangan mengetahui bahwa ia telah melakukan perbuatan hukum, sehingga akan mengeliminasi adanya inconsiderate engagement;

3. Persetujuan (approval): tanda tangan melambangkan adanya persetujuan atau otorisasi terhadap suatu tulisan (Sajadi, 2015).

\section{Peran Notaris dalam Penanda- tanganan Akta Otentik}

Notaris mempunyai peran untuk memberikan penyuluhan hukum sehubungan dengan pembuatan akta. Notaris juga mempunyai kewenangan untuk mengesahkan tanda tangan dan menetapkan kepastian tanggal surat di bawah tangan dengan mendaftar dalam buku khusus. Di dalam akhir atau penutup akta yang dibuat dihadapan notaris memuat uraian tentang penandatanganan dan tempat penandatanganan atau penerjemahan akta jika ada. Dalam membuat akta otentik, penandatangan menjadi hal yang wajib dibubuhkan oleh penghadap karena akta otentik yang dibuat dihadapan notaris dalam hal ini minuta akta adalah asli akta yang mencantumkan tanda tangan para pengadap, saksi, dan notaris. Pada dasarnya, fungsi tanda tangan adalah menjamin kepastian tanggal dan untuk menjamin para pihak tidak mengelak tentang isi akta sehingga akan mengikat secara hukum bagi para pihak (Sudiharto, 2015). Penandatangan dalam akta adalah membubuhkan nama si penandatangan, membubuhkan paraf, dan ditulis tangan oleh si penandatangan sendiri atas kehendaknya sendiri (Mawartiningsih \& Maryanto, 2017). Penghadap tersebut harus memenuhi syarat paling rendah berumur 18 (delapan belas) tahun atau telah menikah dan cakap melakukan perbuatan hukum. Tanda tangan pada suatu akta otentik tersebut sebagai tanda persetujuan terhadap hak-hak maupun kewajiban-kewajiban yang melekat pada akta yang dibuatnya.

Penandatangan dalam akta merupakan syarat mutlak yang harus ada dan dinyatakan secara tegas pada akhir akta, kecuali seseorang tidak bisa membubuhkan tanda tangan harus memberikan alasan secara tegas dan ditulis dalam akta tersebut sebagai pengganti tanda tangan (Dinaryanti, 2013). Penandatangan harus dilakukan pada saat itu juga oleh penghadap, saksi, dan notaris setelah dibacakannya akta dihadapan pengahadap dengan dihadiri oleh paling sedikit 2 (dua) orang saksi, atau 4 (empat) orang saksi khusus untuk pembuatan akta wasiat di bawah tangan. Oleh sebab itu, notaris harus hadir secara fisik dan menandatangani akta dihadapan penghadap 
dan saksi.

\section{Kecakapan Hukum dan Legalitas Tanda Tangan Seorang Terpidana dalam Menandatangani Akta Otentik}

Kaitannya dengan terpidana sebagai salah satu penandatangan akta, terlebih dahulu diuraikan tentang tersangka dan terpidana, untuk mengetahui keberadaannya masing-masing. Tersangka menurut Pasal 1 angka 14 Kitab Undang-Undang Hukum Pidana (selanjutnya disebut KUHAP) adalah seorang yang karena perbuatannya atau keadaannya berdasarkan bukti permulaan patut diduga sebagai pelaku tindak pidana. Terdakwa menurut Pasal 1 angka 15 KUHAP adalah seorang tersangka yang dituntut, diperiksa dan diadili di sidang pengadilan, dan terpidana menurut Pasal 1 angka 32 KUHAP adalah seorang yang dipidana berdasarkan putusan pengadilan yang telah memperoleh kekuatan hukum tetap. Seseorang jika berdasarkan bukti permulaan patut diduga sebagai pelaku tindak pidana, maka disebut sebagai tersangka. Tersangka ditetapkan oleh penyidik didasarkan atas penyidikan. Penyidikan adalah serangkaian tindakan penyidik dalam hal dan menurut cara yang diatur dalam undang-undang ini untuk mencari serta mengumpulkan bukti yang dengan bukti itu membuat terang tentang tindak pidana yang terjadi. Guna menemukan tersangkanya sebagaimana Pasal 1 angka 2 KUHAP, didasarkan atas penyelidikan adalah serangkaian tindakan penyelidik untuk mencari dan menemukan suatu peristiwa yang diduga sebagai tindak pidana guna menentukan dapat atau tidaknya dilakukan penyidikan menurut cara yang diatur dalam undang-undang ini sebagaimana Pasal 1 angka 5 KUHAP. Hal ini berarti terdapat suatu perbedaan antara tersangka dengan terpidana. Jika tersangka, pelaku masih disangka sebagai pelaku tindak pidana dan biasanya ditahan di rumah tahanan negara, sedangkan terpidana adalah orang yang terbukti secara sah dan meyakinkan melakukan tindak pidana berdasarkan putusan pengadilan yang telah mempunyai kekuatan hukum tetap dan menjalani pidana di lembaga pemasyarakatan.

Pasal 44 UUJN-P disebutkan bahwa setiap akta yang dibuat di hadapan notaris harus ditandatangani oleh para pihak, saksisaksi dan notaris. Arti kata "menandatangani" (ondertekenen) secara etimologis (ilmu asalusul kita) berarti memberi tanda (teken) di bawah sesuatu. Dalam praktek, definisi tersebut tidak memberikan gambaran yang jelas dan spesifik mengenai pengertian menanda tangani. Memberikan tanda di bawah sesuatu tersebut tentu terkait perbuatan hukum yang dilakukan oleh subjek hukum (Mardheana, 2016). Oleh karena itu, tindakan pembubuhan tanda tangan merupakan tindakan hukum yang tidak dapat dilepaskan dari tugas rutin seorang notaris dari wewenangnya membuat akta otentik.

Pasal 16 ayat (1) huruf m UUJN-P menyatakan bahwa setiap penutup akta notaris disebutkan kalimat "Setelah saya, notaris membacakan akta ini kepada para penghadap dan para saksi, maka segera para penghadap, para saksi dan saya, notaris menandatangani akta ini”. Semua akta notaris harus ditandatangani oleh masing-masing penghadap, segera setelah selesai pembacaan akta itu, yang berarti bahwa setelah akta dibacakan, kemudian akta tersebut ditandatangani oleh penghadap, saksi dan kemudian oleh notaris. Kata segera menandatanganinya akta tersebut, yang berarti bahwa setelah akta dibacakan, segera para pihak, saksi dan notaris menandatanganinya, tanpa ada tenggang waktu.

Apabila para penghadap menerangkan tidak dapat membubuhkan tanda tangannya dalam akta atau berhalangan untuk melakukannya, maka keterangan itu dan juga sebab-sebab yang menjadikan halangan itu harus diberitahukan oleh notaris secara tegas dalam akta itu. Akta dalam bentuk otentik maupun di bawah tangan tidak dapat dikatakan sebagai akta kalau tidak ditandatangani. Apabila penghadap tidak dapat membubuhkan tanda tangan yang disebabkan karena lumpuh, sakit keras, atau sebab yang lain maka sebagai pengganti tanda tangan maka penghadap tersebut dapat membubuhkan sidik jari pada minuta akta. Hal ini berarti bahwa tidak ada alasan orang yang berada dalam lembaga pemasyarakatan untuk menjalani sanksi pidana yang telah mempunyai kekuatan hukum tetap. Jika dikaitkan dengan kecakapan bertindak dalam 
hukum sebagaimana Pasal 1330 KUHPerdata, tidak ada yang menyebutkan bahwa orang yang ada di dalam lembaga pemasyarakatan menjalani sanksi pidana dinyatakan tidak cakap bertindak dalam hukum, sehingga selama ia telah berusia 18 tahun atau telah kawin dan tidak berada di bawah pengampuan, maka setiap orang adalah cakap bertindak dalam hukum. Sebagaimana ditentukan dalam Pasal 1 ayat (3) KUHPerdata yang menyatakan bahwa tiada suatu hukuman pun yang mengakibatkan kematian perdata, atau hilangnya segala hak kewargaan.

Akta yang dibuat di hadapan notaris tidak cukup memenuhi bentuk dan sifat akta sebagaimana tertuang dalam Pasal 38 UUJN$\mathrm{P}$ sebagai persyaratan akta otentik, melainkan akta tersebut juga harus dibuat didasarkan atas prosedur atau proses pembuatan akta, agar akta tersebut sah sebagaimana akta otentik yang mempunyai kekuatan pembuktian sempurna. Prosedur pembuatan akta yang dibuat di hadapan notaris terdiri dari proses sebagai berikut (Adjie, 2013):

1. Mengidentifikasi penghadap berdasarkan identitasnya yang diperlihatkan kepada notaris;

2. Memahami kehendak, maksud, dan tujuan para pihak tersebut;

3. Memverifikasi bukti surat yang berkaitan dengan kehendak para pihak;

4. Memberikan penyuluhan hukum terkait akta untuk memenuhi keinginan atau kehendak para pihak;

5. Melaksanakan semua prosedur pembuatan akta notaris, seperti pembacaan, penandatanganan, memberikan salinan dan pemberkasan untuk minuta;

6. Menjalankan kewajiban lain berdasarkan tugas jabatan notaris yang telah diatur dalam Undang-Undang Jabatan Notaris .

Rangkaian proses pembuatan akta sebagaimana di atas dalam upayanya untuk menerapkan prinsip kehati-hatian dalam pembuatan akta dengan harapan agar akta yang dibuat notaris tidak bermasalah di kemudian hari. Dalam memeriksa, notaris yang berkaitan dengan akta yang dibuat atau dibuat oleh notaris yang bersangkutan, parameternya harus merujuk pada prosedur pembuatan akta dalam Undang-Undang Jabatan Notaris. Jika semua prosedur sudah dilakukan, maka akta yang bersangkutan tetap mengikat para subjek hukumnya dan mempunyai kekuatan hukum.

Notaris melakukan pengenalan terhadap para penghadap sesuai dengan Pasal 39 ayat (2) UUJN-P yang menyatakan bahwa penghadap harus dikenal oleh notaris atau diperkenalkan kepadanya oleh 2 (dua) orang saksi pengenal yang berumur paling sedikit 18 (delapan belas) tahun atau telah menikah dan cakap melakukan perbuatan hukum atau diperkenalkan oleh 2 (dua) penghadap lainnya. Oleh sebab itu, notaris perlu mengenal para penghadap yang akan melakukan pembuatan akta agar dapat menilai penghadap/pihak tersebut cakap dan berwenang untuk melakukan tindakan pembuatan akta serta tidak termasuk dilarang oleh hukum yang berlaku.

Notaris harus mampu melihat maksud dan tujuan pihak-pihak tersebut membuat akta serta perbuatan hukum ini atas dasar kesepakatan yang tulus bukan ada unsur keterpaksaan, sebagaimana tertulis dalam Pasal 1321 KUHPerdata yang menegaskan bahwa: "tiada sepakat yang sah apabila sepakat itu diberikan karena kekhilafan atau diperoleh dengan paksaan atau penipuan". Apabila maksud dan tujuan pembuatan akta tidak melanggar hukum, ideologi, adat istiadat, budaya maka ditindak lanjuti dengan meminta kelengkapan data/dokumen baik asli maupun kebenarannya. Data pendukung atau dokumen dimaksud antara lain identitas diri, status kependudukan, surat perijinan, surat kepemilikan dan lain-lain, yang harus dicermati dengan teliti keabsahannya. Kemungkinan akibat hukumnya juga harus diterangkan secara jelas dan tegas.

Notaris seharusnya setelah membuat akta, kemudian dilanjutkan dengan melakukan pembacaan, penandatangan akta dan terakhir adalah pemberkasan terhadap minuta. Namun prosedur ini tidak selalu dilakukan dengan benar oleh notaris. Notaris, dalam pembuatan akta, biasanya hanya melihat kondisi penandatangani memenuhi syarat tetapi tidak melihat kondisi fisik penandatangan yang mungkin dalam keadaan tertekan dan lain sebagainya sehingga 
mempengaruhi kebebasan dalam menandatangani akta sebagai suatu bukti adanya perjanjian.

Ketentuan Pasal 19 UUJN-P masuk dalam ranah larangan notaris dalam menjalankan jabatannya, yaitu notaris wajib mempunyai hanya satu kantor, yaitu di tempat kedudukannya, yang berarti bahwa notaris dalam menjalankan jabatannya dilarang memiliki lebih dari satu kantor atau bahwa notaris dilarang menjalankan jabatan di luar kedudukannya. Dikaitkan dengan Pasal sebelumnya yaitu Pasal 18 UUJN-P Notaris mempunyai tempat kedudukan di daerah kabupaten atau kota, notaris mempunyai wilayah jabatan meliputi seluruh wilayah provinsi dari tempat kedudukannya. Meskipun notaris mempunyai wilayah jabatan meliputi seluruh wilayah provinsi, tetapi tempat kedudukan di daerah kabupaten/kota. Notaris dalam menjalankan jabatannya hanya sebatas wilayah seluruh provinsi di mana kantor notaris tersebut berada sehingga jika notaris menjalankan jabatannya membuat akta otentik di luar wilayah provinsi adalah tidak diperkenankan. Akan tetapi, ketentuan tersebut menjadi rancu jika dikaitkan dengan ketentuan Pasal 19 ayat (3) UUJN-P, bahwa Notaris tidak berwenang secara berturut-turut dengan tetap menjalankan jabatan di luar tempat kedudukannya. Hal ini disebabkan karena di satu sisi notaris mempunyai tempat kedudukan di daerah kabupaten atau kota dalam satu wilayah provinsi, namun di sisi yang lain, notaris tidak memiliki wewenang atau dilarang secara berturut-turut dengan tetap menjalankan jabatan di luar tempat kedudukannya, yang berarti masih dalam kedudukan di kabupaten/kantor.

Apabila dikaitkan dengan keabsahan akta notaris yang ditandatangi terpidana di dalam lembaga pemasyarakatan ketika itu penghadap menjalani sanksi pidana penjara, meskipun terpidana berada di lembaga pemasyarakatan, cakap bertindak menurut hukum, maka akta yang ditandatangani sebagai suatu bentuk perjanjian adalah sah dan memenuhi syarat cakap dalam membuat perjanjian. Namun, karena akta tersebut ditandatangani notaris di luar kantor notaris yang bersangkutan, maka perlu dipertanyakan akibat hukum terhadap akta tersebut. Di satu sisi notaris menandatangani akta di kantor notaris, namun masih dimungkinkan notaris menandatangani akta di luar kantor notaris selama tidak dilakukan secara berturut-turut, sebagaimana Pasal 19 ayat (3) UUJN-P, bahwa notaris tidak berwenang secara berturut-turut dengan tetap menjalankan jabatan di luar tempat kedudukannya. Hal ini berarti bahwa selama penandatanganan akta ketika terpidana menjalani masa pidana di lembaga pemasyarakatan masih dalam lingkup kedudukan notaris di kabupaten/kota atau di luar kedudukannya namun masih dalam wilayah jabatan meliputi seluruh wilayah provinsi dari tempat kedudukannya, dan tidak dilakukan secara bertutut-turut dan dengan tetap menjalankan jabatan di luar tempat kedudukannya, maka tandatangan yang demikian adalah tidak dilarang. Berkaitan dengan notaris yang menandatangani akta tidak di kantor notaris, melainkan di rumah tahanan negara, selama notaris menandatangani akta tersebut tidak dilakukan secara berturut-turut sebagaimana Pasal 19 ayat (3) UUJN-P, maka masih hal tersebut tidak dilarang.

\section{Simpulan dan Saran}

Kecakapan hukum seorang terpidana yang berada di lembaga pemasyarakatan menandatangani akta notaris, bahwa terpidana yang menjalani pemidanaan di lembaga pemasyarakatan cakap bertindak dalam hukum dengan menandatangani atau menjadi akta di hadapan notaris. Tidak ada alasan orang yang berada dalam lembaga pemasyarakatan untuk menjalani sanksi pidana yang telah mempunyai kekuatan hukum tetap. Jika dikaitkan dengan kecakapan bertindak dalam hukum sebagaimana pasal 1330 KUHPerdata tidak ada menyebut bahwa orang yang ada dalam lembaga pemasyarakatan menjalani sanksi pidana dinyatakan tidak cakap bertindak dalam hukum, sehingga selama telah berusia 18 tahun atau telah kawin dan tidak berada di bawah pengampuan, maka setiap orang adalah cakap bertindak dalam hukum. Sebagaimana ditentukan dalam pasal 1 ayat (3) KUHPerdata bahwa tiada suatu hukuman pun yang mengakibatkan kematian perdata, atau hilangnya segala hak kewargaan. 
Tanda tangan seorang terpidana yang sedang berada di Lembaga Permasyarakatan tetap sah menurut hukum asalkan seorang terpidana tersebut tidak dicabut hak keperdataannya oleh putussan pengadilan. Meskipun seorang terpidana yang menjalani hukuman di lembaga pemasyarakatan cakap bertindak dalam hukum dengan menandatangani akta notaris, namun hendaknya notaris tidak secara berturut-turut menandatangani akta di luar kantor, karena selain mempengaruhi otensitas akta juga menghindari sanksi bagi notaris yang bersangkutan. Notaris juga harus mempertimbangkan aspek dari pihak yang akan menandatangani akta yang dibuatnya, apakah pihak tersebut dalam keadaan sehat, tidak tertekan, maupun tidak ada paksaan dari siapapun untuk menandatangani akta tersebut.

\section{DAFTAR PUSTAKA}

Adjie, H. (2013). Menjalin PemikiranPendapat tentang Kenotariatan. Bandung: Citra Aditya Bakti.

Arifianto, D., Rato, D., \& Sriono, E. (2014). Kecakapan Seseorang Dalam Melakukan Perbuatan Hukum Menurut Hukum Adat Suku Tengger.

Closen, M. (1999). Document Authentication in Electronic Commerce: The Misleading Notary Public Analog for the Digital Signatre Certification Authority. The John Marshall Journal of Information Technology \& Privacy Law, 17(3), 833872.

Closen, M., Ahlers, G., Jarvis, Morris, \& Spyke. (1997). Notary Law \& Practice: Cases \& Materials. Chatsworth: National Notary Association.

Dewi, I. (2008). Pelaksanaan Hak dan Kewaiban Perdata Orang yang Tidak Cakap Hukum di Kabupaten Sleman. Mimbar Hukum, 20(3), 559572.

Dinaryanti, A. (2013). Tinjauan Yuridis Legalisasi Akta Di Bawah Tangan Oleh Notaris. Jurnal Ilmu Hukum Legal Opinion, 1(3), 5.

Fuady, M. (2010). Perbuatan Melawan Hukum: Pendekatan Kontemporer. Bandung: Citra Aditya.
Gnoffo, V. (1997). Notary Law and Practice for the 21st Century: Sugessted Modifications for the modal Notary Act. J. Marshall. L. Rev, 30, 10631097.

Handayani, T. (2009). Pengakuan Tanda Tangan Pada Suatu Dokumen Elektronik di Dalam Pembuktian Hukum Acara Perdata di Indonesia. Universitas Diponegoro.

Hernoko, A. (2010). Hukum Perjanjian Asas Proporsionalitas dalam Kontrak Komersial. Jakarta: Kencana Prenada Media Group.

Hikmah, N. (2015). Analisis Terhadap keragaman Batas Umur Anak Ditinjau Menurut Peraturan PerundangUndangan dan Putusan Hakim Dalam Perkara Perdata di Pengadilan Negeri. Jurnal Ilmu Hukum, 3(1), 6675.

Ismamuddin. (2010). Kecakapan Bertindak (Studi Komparisi Dalam Hukum Pidana Positif dan Hukum Pidana Islam. Universitas Islam Negeri Sunan Kalijaga.

Kambey, P. (2013). Peran Notaris Dalam Proses Peradilan Pidana. Lex Et Sociatatis, 1(2), 2738.

Lestari, N. (2008). Kecakapan Bertindak Dalam Melakukan Perbuatan Hukum Setelah Berlakunya Undang-Undang Nomor 30 Tahun 2004 Tentang Jabatan Notaris. Universitas Diponegoro.

Mardheana, D. (2016). Implikasi Yuridis Pemalsuan Tanda Tangan Pada Minuta Akta terhadap Jabatan Notaris (Studi Putusan Mahkamah Agung Nomor $1234 \mathrm{~K} / \mathrm{Pid} /$ 2012). Jurnal Lex Renaissance, I(2), 285.

Mawartiningsih, A., \& Maryanto. (2017). Tinjauan Yuridis Praktek Pembuatan Akta Notaris Dalam Hal Penghadap Menghadap Dalam Kurun Waktu Dan Tempat Yang Berbeda. Jurnal Akta, 4(2), 119124.

Rahman, M. (2014). Kewenangan, Kewajiban Notaris dan Calon Notaris dalam Membuat Akta Autentik. Jurnal Hukum, 1020.

Rains, S., \& Young, A. (2006). A Sign of the times: an Analysis of Organizational Members email Signatures. Journal of Computer-Mediated Communication, 11(4), 10461061. 
Ramelan, S. (1986). Peranan Notaris Dalam Pembangunan. Jurnal Hukum \& Pembangunan, 16(4), 352358.

Sajadi, I. (2015). Tanggung Jawab Notaris Terhadap Keabsahan Akta Notaris Yang Dibuatnya Atas Penghadap Yang Tidak Dapat Membaca dan Menulis. Jurnal Repertorium, II(2), 182.

Sherblom, J. (1988). Direction, Function, and Signature in Electronic Mail. International Journal of Business Communication, 25(4), 3954.

Stia, D. (2008). Peranan Notaris Dalam Proses Peradilan Kaitannya Dengan Kewajiban Menjaga Kerahasiaan Jabatan di Kota Surakarta. Universitas Diponegoro.

Subekti, H. (2006). Tugas Notaris Perlu Diawasi. Jurnal Renvoi, Ketiga(26), 40.

Sudiharto. (2015). Keotentikan Akta Jaminan Fidusia Yang Tidak Ditandatangani Di Hadapa Notaris. Jurnal Pembaharuan Hukum, II(3), 412418. 